\section{Leuwigajah, Sebuah Catatan}

Oleh Ir. GEDE H. CAHYANA, M.T.

SEKEJAP saja, ratusan nyawa manusia lenyap di TPA Leuwigajah pada dini hari Senin, 21 Februari lalu. Pada malam yang sama, Baleendah, Dayeuhkolot, Bojongsoang, Rancaekek, Panyileukan, Gedebage, dan Riung Bandung dilanda banjir. Banjir terbesar sejak 1986, kata warga setempat. Dua peristiwa berbeda, sebabnya juga berbeda, namun sama-sama menyedihkan. Rugi harta benda dan nyawa tak terhitung nilainya. Keduanya, dan ini patut dicatat, berisi unsur "malapraktik" manusia, baik pejabat pemerintah daerah maupun rakyat yang menjadi korban.

Yang pertama, dan ini yakin seyakin-yakinnya, pengoperasian TPA tersebut tak sesuai dengan perencanaan (planning) dan perancangannya (designing). Sedikit pun tak ada pengaturan. Sampah yang datang langsung ditumpahkan begitu saja dari truk lalu balik kanan, grak! Pergi lagi, menoleh pun tak mau. Wajarlah terjadi penumpukan gas metana (CH4) di suatu bagian massa sampah. Makin lama kian terakumulasi, lalu akhirnya... bumm!

\section{ARSIF}

$\gg$ EDISI 2004-2005

\section{WEBMAIL}

X WebMail

Yang kedua, tidak ada kepedulian Pemkot Bandung, Cimahi, dan Pemkab Bandung. Kalaupun peduli, sebatas retorika; itu pun sedikit sekali. Terlalu berpikir bahwa sampah hanyalah sampah, berbau busuk, lantas tak mendapat perhatian serius. Padahal kalau salah kelola, penyakit bisa mewabah, lingkungan rusak, air tanah tercemar, dan... meledak. Mayat-mayat pun tertimbun.

Yang ketiga, pihak warga, hendaklah menaati peringatan (warning) pemerintah. Sebab, peringatan itu didasarkan pada kajian sains dari kalangan ahli. Tak percaya pada ahlinya dapat mengakibatkan kerugian yang tak tertanggungkan. Pada saat yang sama, pemerintah pun wajib mencarikan lahan buat masyarakatnya agar tidak mukim di dekat TPA. Sebab, logikanya, TPA itu harus dibuat di daerah yang nilai ekonomi tanahnya rendah dan rendah pula potensi polusinya terhadap air tanah.

Lepas dari hal di atas, sebetulnya "bencana" yang terkait dengan sampah tak hanya di Leuwigajah. Masih banyak TPA lain yang bermasalah. Sebanyak 99\% TPA kita sarat masalah. Kalau tidak bau masalahnya, transportasilah masalahnya; kalau bukan kedua hal tersebut, "izin" dari masyarakatlah masalahnya; kalau bukan ketiga hal itu, teknologinya yang bermasalah; kalau bukan semua itu, retribusilah masalahnya. Masih ada masalah-masalah lainnya.

Lantaran "bencana" tersebut, banyaklah TPA, seperti Bantar Gebang, Bekasi, dan terakhir tempat pembuangan sampah terpadu di Bojong, Bogor yang menuai protes. Sebelum ledakan itu, konflik soal TPA tersebut dan TPA Jelekong telah santer di media massa. Intinya adalah masalah retribusi dari Pemkot Bandung kepada Pemkab Bandung (sebelum Kota Cimahi terbentuk).

Bahkan jauh sebelum itu, TPA tersebut sering diprotes lantaran bau busuknya yang menyengat ke mana-mana dan ruas jalan yang dilalui truk-truk sampah menjadi kotor dan rusak. Warung-warung nasi, rumah tinggal, dan kehidupan warga kerap terganggu oleh suara bising, lalu lintas semrawut dan kecelakaan. Malah ada janji-janji, seperti kasus Bantar Gebang, akan dijadikan pusat listrik tenaga biogas (metana). Tapi nyatanya, warga protes dan TPA tutup. Secara teoretis, dari $1.000 \mathrm{~kg}$ COD air sampah dihasilkan 12 juta BTU (British Thermal Unit) sebagai metana; 10.000 BTU sekira $1 \mathrm{KWH}$.

Meski terbatas, energi inilah sisi positif sampah (organik) yang bernilai ekonomi selain kompos. Pemanfaatan energi "sampah" tersebut sebetulnya bisa dirintis di TPA Leuwigajah kalau berupa sanitary landfill (lahan uruk saniter) yang tepat operasi-rawatnya. Tiga pemerintah, yaitu Pemkab dan Pemkot Bandung serta Pemkot Cimahi bisa bekerja sama. Sayang seribu sayang, ledakan "kematian" warga di sekitar TPA sudah terjadi. Lagi pula, TPA itu hanyalah open dumping alias timbunan terbuka yang antilingkungan. Bau busuk, lalat, tikus, dan pencemaran air tanah adalah hasilnya. Boleh jadi sumur warga yang kini tewas itu telah tercemari zat berbahaya dan beracun dari TPA itu. Sangat boleh jadi. 
Sekolah, mulai dari SD, atau bahkan TK, harus berupaya mengubah paradigma berpikir masyarakat. Dalam buku-buku pelajaran, selama ini sampah selalu dikatakan tak berguna. Guru dan orang tua selalu bilang, buanglah sampah pada tempatnya. Ini tidak salah. Tapi yang lebih baik, ganti dengan kalimat: kurangi sampah, pilah-pilah mana organik mana plastik dan kertas, lalu letakkan (bukan buanglah) di bak sampah. Plastik dan kertas bisa dijual (diberikan) ke pemulung (tukang rongsok) dan yang organik dikubur di halaman. Tanah pun gembur dan subur.

Seandainya tak ada upaya mengubah paradigma lama itu, banyaklah yang enggan bersahabat dengan sampah. Jangankan bersahabat, berlama-lama dengan sampah saja tak mau. Padahal, dalam keseharian kita dekat dengan sampah. Kitalah yang dominan menimbulkan sampah, baik sampah industri maupun rumah tangga.

Sampah industri terdiri atas sisa-sisa bahan kegiatan industri: rubbish, debu, dan limbah berbahaya. Sangat riskan lantaran korosif, reaktif, radioaktif, eksplosif, dan lain-lain. Adapun sampah rumah tangga berasal dari kegiatan dapur seperti sisa sayuran, daging, dan buah-buahan (garbage). Lantaran mudah membusuk, dapat dijadikan pupuk. Yang lain adalah plastik, kain perca, kaleng, dan lain-lain (rubbish). Kelompok ini bisa didaur ulang atau digunakan kembali atau disedekahkan ke pemulung. Malah pemulung sebaiknya dikelola agar terkoordinasikan dengan baik dan mengurangi dampak negatif seperti pencurian dan kecurigaan dari warga.

Manfaat lainnya, untuk reklamasi lahan dan pantai, bahan batako, dan pedestrian. Juga untuk urukan dan memperbaiki tekstur tanah agar limpasan air hujan berkurang dan banjir pun hilang. Bahkan di Jepang, sampah sudah dijadikan bahan konstruksi pembuatan rumah permanen. Tentu perlu dikaji aspek kesehatannya terutama sampah radioaktif. Kedua jenis sampah tersebut, rumah tangga dan industri, bisa diduga masuk ke TPA. Tentu saja sampah domestik yang terbanyak dibuang ke TPA. Inilah masalah konsistensi dan taat asas pada peraturan yang dibuat.

Lebih dari itu semua, paradigma baru, yaitu kurangi volume sampah, adalah solusi terbaik. Gunakan bahan baku yang dapat digunakan lagi (reuse) atau dapat didaur ulang (recycle). Andaikata sudah demikian, pada masa depan, kebutuhan lahan untuk TPA bisa dikurangi, malah dapat dijadikan permukiman atau aktivitas komersial lainnya. TPA lama pun bisa digunakan lagi berulang-ulang kalau proses degradasinya sudah tuntas.

Juga, usahlah takut bersahabat dengan sampah; mengelola sampah dengan ramah lingkungan, membangun atau berproduksi (domestik, komersial dan industri) sembari tak merusak alam. Kurangilah timbulan sampah, sediakan TPA (bukan tempat pembuangan akhir, melainkan pengolahan akhir) yang ramah lingkungan. Setelah itu, laksanakan penanganan yang sesuai standar prosedur operasi-rawat, baik itu di area koleksi, penampungan sementara, transportasi, dan pembuangannya (pengolahannya).

Akhir catatan, pascaledakan Leuwigajah, karena sampah terus muncul setiap hari, mengurangi volume sampah lalu memilahnya menjadi "busuk" dan "tak busuk", akan membantu mereduksi tumpukan sampah di TPS. Ini akan menyamankan hidung dan mata kita ketika melintas di TPS. Di lain pihak, yakni tiga pemerintah daerah tersebut, secepatnya mencari lokasi TPA alternatif. Ketiga pemerintah itu bisa berkontribusi sama dengan satu tujuan, mereduksi pencemaran air tanah, menghindari polusi bau, dan murah biaya operasi-rawatnya.

Mudah-mudahan perubahan paradigma segera dirintis di sekolah (SD, SMP, SMU) lewat kebijakan pemerintah dalam menata kurikulum ramah lingkungan. Mari tingkatkan "gengsi" sampah. Jadikanlah "tambang emas" potensial, khususnya bagi pemulung. Mari ubah sampah menjadi sahabat penuh manfaat bukan musuh yang harus dijauhi.***

Penulis, Dosen Teknik Lingkungan Universitas Kebangsaan, Bandung dan Alumni Teknik Lingkungan ITB. 